MIRKO RAGUŽ

\title{
AKADEMIK MILAN MOGUŠ, SENJANIN (25. 4. 1927. - 19. 11. 2017.)
}

Mirko Raguž

Ivana Lenkovića 24

HR 53270 Senj

mirko.raguz2@inet.hr
UDK: 929Moguš,M.

821.163 .42

Stručni članak

Ur.: 2018-7-6

Među tridesetak senjskih sveučilišnih profesora i znanstvenika ime akademika Milana Moguša zauzima istaknuto mjesto. Njegov životni hod od trnja do zvijezda, ili kranjčevićevski, od gnijezda do zvijezda bio je stalno u usponu. U vrijeme radnoga vijeka zauzimao je značajne funkcije u mnogim kulturnim i znanstvenim institucijama diljem Hrvatske, ali i šire, i to ga je stalno držalo u nemogućnosti da se češće navraća u njemu rodni i dragi Senj. Boravio je uvijek u njemu kad god mu se pružila prilika i kad god su mu njegovi Senjani izrazili želju da ih posjeti. Bio je čest gost Gradskog muzeja u Senju, Senjske gimnazije, ali i Osnovne škole S. S. Kranjčevića u kojoj je u dječačkim danima učio prva slova i čitao prve školske knjige. Ta njegova povezanost sa senjskim kulturnim institucijama nizom godina manje je poznata širokoj kulturnoj i znanstvenoj javnosti pa će stoga biti tema ovoga članka.

Ključne riječi: Senj, gimnazija, Gradski muzej, Osnovna škola

Milan Moguš rođen je 25. travnja 1927. u Senju od oca Ličanina (iz Čovića kod Otočca) i majke Senjkinje. Otac Matija došao je u Senj kao dječak i tu ostao i oženio se Kristinom Bašić. U tome braku imali su tri kćeri i jednoga sina.

Milan uspješno završava osnovnu školu, a za vrijeme gimnazijskih dana 1945. godine partizani mu ubijaju oca, dok mu je iste godine umrla i majka. Nakon završetka gimnazije 1948. godine upisao se na Filozofski fakultetu Zagrebu (8. grupa predmeta: Narodni jezik i književnost). Diplomirao je 1953. godine. Još kao student pokazivao je posebnu sklonost prema jezičnim kolegijima pa je odmah nakon diplomiranja izabran za asistenta u Akademijinom institutu za jezik. Godine 1956. prelazi u istom zvanju na Filozofski fakultet Sveučilišta u Zagrebu (Katedra za dijalektologiju i povijest hrvatskoga jezika). 
Od 1961. do 1963. godine bio je lektor hrvatskoga jezika na Sveučilištu u Varšavi. Istodobno je pohađao studij slavistike i polonistike na Odjelu za slavistiku i filologiju Sveučilišta u Varšavi. Doktorat filoloških znanosti stekao je 1962. na Zagrebačkom sveučilištu, obranivši disertaciju pod naslovom Današnji govor senjski. Godine 1964. izabran je za docenta, 1969. za izvanrednoga, a 1975. za redovnoga sveučilišnog profesora na Filozofskom fakultetu u Zagrebu. Od godine 1965. na dužnosti je šefa Katedre za povijest hrvatskoga jezika i dijalektologiju. Godine 1970/71 i 1971/72 bio je prodekan Filozofskoga fakulteta u Zagrebu. Na istome fakultetu od 1976. predavao je na postdiplomskome studiju smjera lingvistike, a od 1979. do 1985. bio je voditelj toga postdiplomskog studija. Od 1983. godine predstojnik je Zavoda za lingvistiku Filozofskoga fakulteta. Školske godine 1969./70. i 1973./74. predavao je kao gostujući profesor na Pedagoškom fakultetu u Rijeci i na Pedagoškom fakultetu u Osijeku.

Sudjelovao je na mnogim domaćim i međunarodnim slavističkim i onomastičkim skupovima i kongresima u tuzemstvu i inozemstvu (Bern, Krakov, Varšava, Prag, Berlin, Bratislava, Leipcig Sofia, Helsinki, Ljubljana, Pula, Santiago De Compostela, Washington). Godine 1977. izabran je za izvanrednoga, a 1986. za redovnoga člana JAZU. Od 1997. do 2004. vršio je dužnost potpredsjednika HAZU, dok je od 2004. do 2010. bio predsjednik te najveće znanstvene ustanove u Hrvatskoj. Umirovljen je 1992. godine kao redovni sveučilišni profesor.

Za vrijeme svoje blistave znanstvene karijere dobio je niz priznanja i odlikovanja: nagrada "Božidar Adžija" za značajnu znanstvenu djelatnost u području filologije (1990.), nagrada "Josip Juraj Strossmayer" za knjigu Povijest hrvatskoga književnog jezika (1993.), Nagrada Grada Senja (1994.), Orden Danice hrvatske s likom Ruđera Boškovića (1996.), Državna nagrada Republike Hrvatske za životno djelo na području humanističkih znanosti (1998.), Povelja i medalja "Zlatni grb grada Splita" za posebne zasluge u proučavanju djela Marka Marulića (2001.) i niz drugih priznanja. Objavio je više od 253 znanstvena, stručna i urednička rada. Sam ili u suautorstvu objavio je 31 knjigu te iz područja hrvatske i slavenske filologije i lingvistike više od 60 domaćih i stranih časopisa. ${ }^{1}$

Milan Moguš bio je za života jedan od vodećih kroatista i slavista $u$ Republici Hrvatskoj. To dokazuje i njegova bogata bibliografija od dijalektologije

1 MATICA HRVATSKA SENJ, 2002. 
pa sve do leksikografije, frazeologije i kompjutorske lingvistike. S obzirom na to da je tema ovoga rada Moguševa povezanost sa Senjom i senjskim kulturnim institucijama, odredit ću se samo na one podatke do kojih sam došao ili koje sam zabilježio surađujući s njim kao osnovnoškolski ravnatelj.

\section{Značajan suradnik Senjskog zbornika}

Još kao student, a i kasnije kao profesor često je dolazio u Senj, družio se sa svojim prijateljima i znancima. Posebice je ta suradnja sa Senjom učvršćena kada je nakon osnivanja Gradskog muzeja i Senjskog muzejskog društva uspostavljena suradnja na znanstvenom časopisu Senjski zbornik s prof. Antom Glavičićem, koji mu je bio vrlo blizak po "životnom nazoru". U predgovoru Senjskog rječnika Moguš kaže: "Ali, osim znanstvenog interesa postoji posebna moja naklonost prema gradu pod Nehajem jer sam u Senju rođen, odgojen i školovan."2 Često je navraćao u Muzej i kako sam reče: "Tu sam se nekako osjećao ugodnim, bio sam kao doma." ${ }^{3}$

Ta njegova suradnja rezultirala je odmah u drugom svesku Senjskog zbornika objavom disertacije pod naslovom Današnji senjski govor ${ }^{4}$. U njezinoj se izradi, kako i sam kaže, "oslanjao na dobre informatore" senjskoga govora. Ovdje je riječ o govoru Senjana "koji su se ili malo ili nikako micali iz mjesta". To je bila dobra prilika, kako navodi autor "da se senjska čakavština zabilježi u svojoj sadašnjoj punini." Kasnije bi zasigurno bilo manje prilika sačuvati i zabilježiti onodobni govor jer se jezik kao živi organizam stalno mijenja i usavršava.

U ovoj spomenutoj suradnji s Gradskim muzejom u Senju i Senjskim muzejskim društvom Moguš je pripremio i napisao ukupno deset priloga isključivo na temu iz njegova stručnoga i znanstvenoga interesa. Nakon spomenutoga rada Današnji senjski govor u 3. broju Senjskog zbornika objavio je članak $O$ Kranjčevićevim pismima Novaku ${ }^{5}$ koji se nalaze u pismohrani Gradskog muzeja u Senju. Radi se o originalnim pismima koje je Kranjčević poslao Vjenceslavu Novaku, a ta pisma je Gradskom muzeju u Senju poklonila Novakova kći Ivka Šnidaršić. Iza ovoga uratka Moguš se javlja novim prilogom opet iz područja njegova znanstvenoga djelovanja - člankom Vitezovićeva Senjčica. ${ }^{6}$ Ovaj prilog

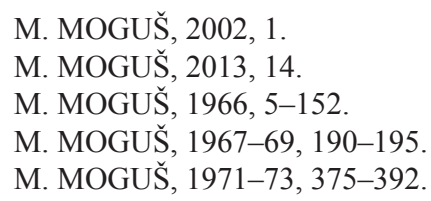


objavljen je u povodu 270. obljetnice događaja što ga je Pavao Ritter Vitezović opjevao, a Moguš uradio da on bude pristupačan široj čitalačkoj javnosti.

U svojemu znanstvenome radu Jezik prijevoda senjskoga statuta ${ }^{7}$ govori o prijevodu senjskoga suca Vuka Ručića iz godine 1701. dajući upute za daljnju obradu toga prijevoda. U istom tome zborniku nalazi se njegov članak pod naslovom Napomene o Vitezovićevu jeziku, ${ }^{8} \mathrm{u}$ koje daje osnovne karakteristike toga jezika, korištenog u Odiljenju sigetskom, njegovu najboljemu pjesničkom radu. Sljedeći Mogušev prilog u Senjskom zborniku je uradak Uskočka epopeja u poeziji $S$. S. Kranjčevića ${ }^{9}$, kojim ističe snažan odnos pjesnika prema svome gradu Senju.

U članku Između Mainza $i$ Senja ${ }^{10}$ piše kako Hrvati kao malobrojan europski narod imaju inkunabule, tj. svoje vlastite knjige, tiskane na vlastitom tlu u prvim desetljećima tiskarstva. Člankom Kako pročitati Bašćansku ploču ${ }^{11}$ Moguš daje odgovor na pitanje kako pročitati uglatom glagoljicom uklesani tekst prvoga hrvatskoga spomenika pronađenoga u crkvici Sv. Lucije u Jurandvoru blizu Baške na otoku Krku. Dao je odgovor kako konačno treba čitati Bašćansku ploču objavivši naznačenu rekonstrukciju u svojoj knjizi Povijesna fonologija hrvatskoga jezika. Ondje je predstavio svoju verziju Bašćanske ploče u suvremenome hrvatskome jeziku.

U povodu 10. obljetnice smrti dugogodišnjeg urednika Senjskog zbornika prof. Ante Glavičića održan je znanstveni skup na kojee su sudjelovali brojni suradnici časopisa Senjski zbornik. Prilozi sa spomenutog skupa objavljeni su u Senjskom zborniku 40, među kojima se nalazi prilog akademika Milana Moguša pod nazivom Senjski zbornik Ante Glavičića. ${ }^{12}$ Autor priloga u tome radu daje ocjenu o Senjskom zborniku, iznoseći svoja sjećanja o suradnji s prof. Antom Glavičićem. Također naglašava i veliko značenje spomenutoga časopisa za Senj i za cjelokupnu senjsku i hrvatsku kulturnu baštinu. Na kraju u svojem zadnjemu prilogu za Senjski zbornik pod nazivom Pričest u Smail-agi ${ }^{13}$ pregledno prikazuje obred pričešćivanja prije borbe Crnogoraca protiv Turaka u poglavlju Četa iz Mažuranićeva djela Smrt Smail-age Čengića.
M. MOGUŠ, $1988,161-68$
M. MOGUŠ, 1988, 161-168.
M. MOGUŠ, 1990, 187-192.
M. MOGUŠ, 2008, 5-10.
M. MOGUŠ, 2010, 33-44.
M. MOGUŠ, 2013, 13-18.
M. MOGUŠ, 2014, 271-276. 


\section{Moguš - počasni senjski građanin}

Moguševa suradnja sa čelnicima Grada Senja bila je jako dobra i ona je uvijek rezultirala kvalitetnim prijedlozima i sugestijama na dobrobit suvremene senjske kulturne javnosti. Od 1991. godine, kada su se događale značajne društvene promjene u cijeloj Republici Hrvatskoj, događale su se i brojne mijene u gradu Senju. Skupština općine Senj tražila je promjenu datuma Dana grada i zbog toga je oformila Odbor za određivanje datuma Dana grada. U taj Odbor ušli su prof. Ante Glavičić, prof. Ante Pađan, Dragan Vlahović, prof. Milan Galić i prof. Milan Moguš. Njihovi su prijedlozi jednoglasno na Skupštini općine Senj prihvaćeni, kao i prijedlozi za određivanje grba i zastave grada Senja. Na zajedničkoj sjednici Vijeća Skupštine općine Senj 15. travnja 1992. donesena je odluka uporabe staroga grba, pečata i zastave grada Senja. Značajan prilog ovim prijedlozima i njihovim prihvaćanjima od strane vijećnika u Senju dao je akademik Moguš. Prijedlozi Odbora imali su uporište u povijesnom i stručnom obrazloženju važnom za cjelokupnu suvremenu senjsku kulturu. Isto tako pri određivanju naziva senjskih ulica, trgova i naselja u novijoj senjskoj povijesti sudjelovao je dr. Moguš i na najbolji način pomagao mjerodavnim gradskim strukturama provedbu i realizaciju odluka na konkretnim činjenicama. Zato je akademik Moguš rado viđen i dobro primljen u njegovome rodnome gradu, pa mu je za njegove zasluge i za sve što je učinio za Senj 1994. dodijeljena Nagradu Grada Senja, a 2004. godine i priznanje počasnog građanina grada Senja. Te je iste godine Moguš postao predsjednik Hrvatske akademije znanosti i umjetnosti čiju je dužnost obavljao sve do 2010.

\section{Metropola jedne mladosti}

Odnos akademika Moguša prema Senjskoj gimnaziji bio je poseban. U tu je ustanovu uvijek dolazio s ponosom, a nikada praznih ruku. Zadovoljstvo mu je bilo sa sobom donijeti knjigu-dvije, svoje ili neke drugoga poznatog autora, samo da Senjska knjižnica posjeduje u svojoj prebogatoj knjižnoj građi ona djela koja zavređuju posebnu pozornost.

Tako na samome ulazu u Knjižnicu danas stoji na vidnom mjestu stalak s više stotina knjiga, poklon akademika Moguša. Na to su posebice ponosni djelatnici Senjske gimnazije, a naročito prof. Marica Mostarac Štokić, knjižničarka i suradnica akademika Moguša. Za akademika Moguša senjska gimnazija žila je kucavica gotovo puna tri stoljeća, stjecište znanja i snažnog ljudskog potencijala. Zašto? U Senju su nerijetko djelovali ponajbolji nastavnici s 
doktoratima i tako stvarali uvjete za kvalitetne buduće stručnjake u najrazličitijim zvanjima. To je i rekao prilikom obilježavanja 275. obljetnice osnutka senjske gimnazije istaknuvši na samome početku svoga govora da su "svu slavu senjske gimnazije pronijeli zapravo njezini učenici..." Ova senjska srednjoškolska ustanova gotovo puna tri stoljeća davala je poseban pečat, poučavajući svoje polaznike da kroz život cijene i poštuju čast, poštenje i svaki posao "pa bio to fakin od porta, ili častan obrtnik". I na samome kraju svoga obraćanja na prije spomenutoj obljetnici reče: "Oni su postali gimnazijsko zvjezdano nebo prolazeći put per aspera ad astra, kroz trnje do zvijezda ili, u verziji senjskoga gimnazijalca i maturanta Silvija Strahimira Kranjčevića, od gnijezda do zvijezda. To je pravim učiteljima mogla biti i bila je najbolja nagrada.......Vjerojatno zato nije poznat slučaj da bi itko zatajio svoje senjsko gimnazijsko školovanje. Upravo obrnuto: već na prvi poziv spustili su se bivši gimnazijalci i gimnazijalke jatimice u Senj osnivajući zacijelo prvi (ta valjda i jedini) klub maturanata svoje gimnazije. Jer, po formuli civis seniensis sum, što su je stoljećima izricali senjski građani u najsvečanijim zgodama, senjski su gimnazijalci uvijek mogli dati do znanja i dokazati znanjem da discipuli gymnasii seniensis sunt. Uostalom, Senj i Gimnazija bijahu metropolom njihove mladosti. Bijahu to, na sreću, i meni."14 Sa zadovoljstvom je isticao da je đak Senjske gimnazije iako slijedom njegovih arhivskih dokumenata u Gimnaziji prof. Moguš nije bio redoviti polaznik. Tome je svakako pridonijelo vrijeme u kojemu je mladi Moguš stasao (rat, gubitak oba roditelja) i bio polaznikom srednjoškolskog obrazovanja. Peti razred završava redovito 31. srpnja 1943., za šesti razred ne nalazim podatak u gimnazijskim knjigama, ali sedmi razred polaže privatno pa mu je svjedodžba izdana 28. kolovoza 1947. Prema ovim podacima vidljivo je da mladi Moguš ne pohađa gimnazijske razrede redovito.

U posebnom Glavnom imeniku za privatiste godine 1941./42., 42./43., 45./46., 46./47. pod rednim brojem 25. Milan Moguš polaže sedmi razred (u napomeni) po odobrenju Ministarstva prosvjete br. $24574-I I I-47$ od 3. V. 1947. $\mathrm{U}$ istoj rubrici (napomene) dodatno je upisano da je latinski jezik polagao 24 . V. 1948. Osmi razred gimnazije završio je školske 1947./48., kako stoji u Glavnom imeniku pod rednim brojem imenika 27. Prvi put polagao je ispit zrelosti od 21. rujna 1948. do 27. studenoga 1948 . Unatoč spomenutim teškoćama u to vrijeme njegova gimnazijskog školovanja, s ponosom je uvijek isticao svoju povezanost sa Senjom, dokazujući je čitavim svojim kulturnim i znanstvenim djelovanjem.

14 M. MOGUŠ, 2000, 161. 


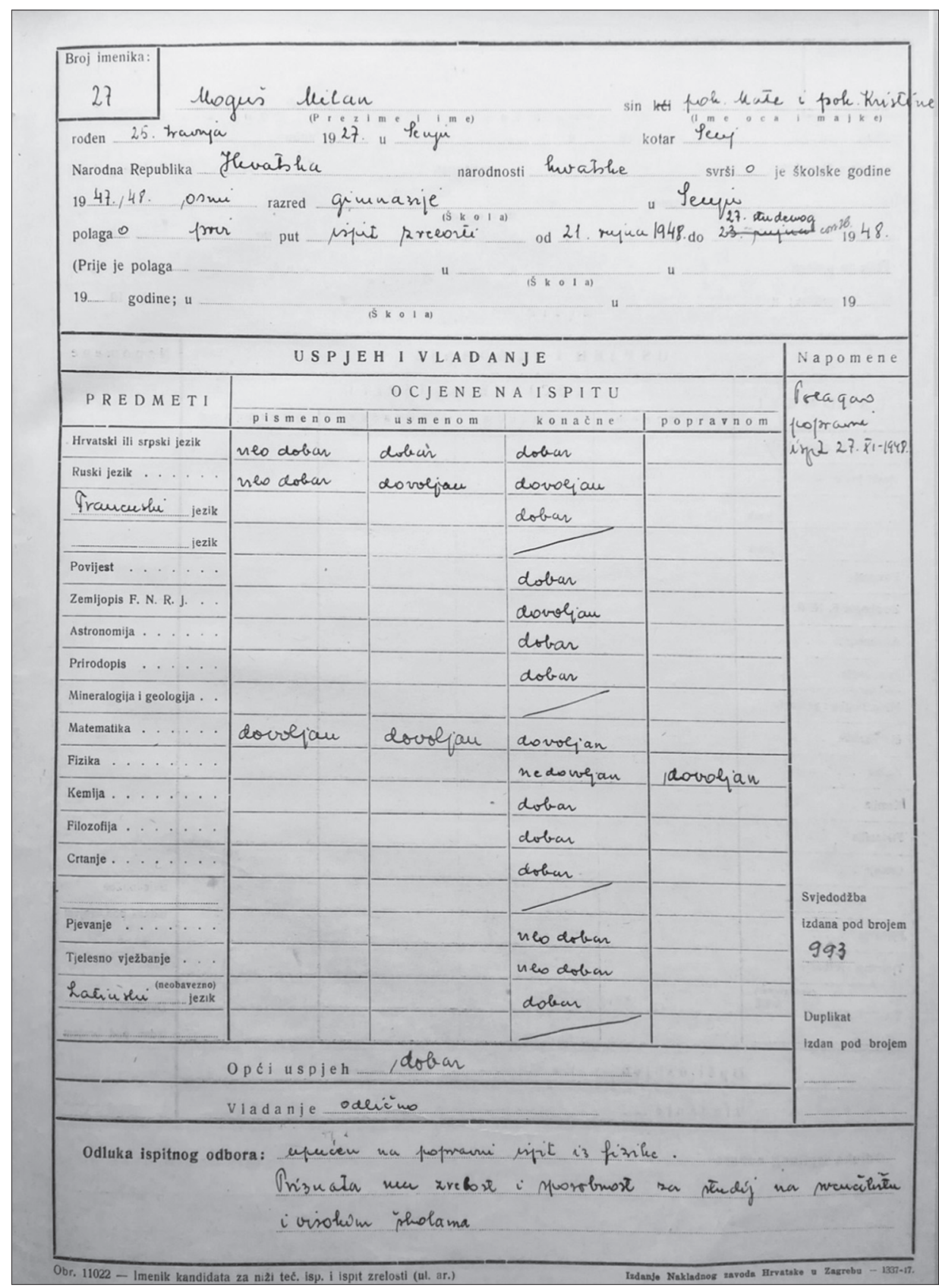

Sl. 1. Preslika iz glavnog imenika školske 1947./48. godine pod rednim brojem 27. 


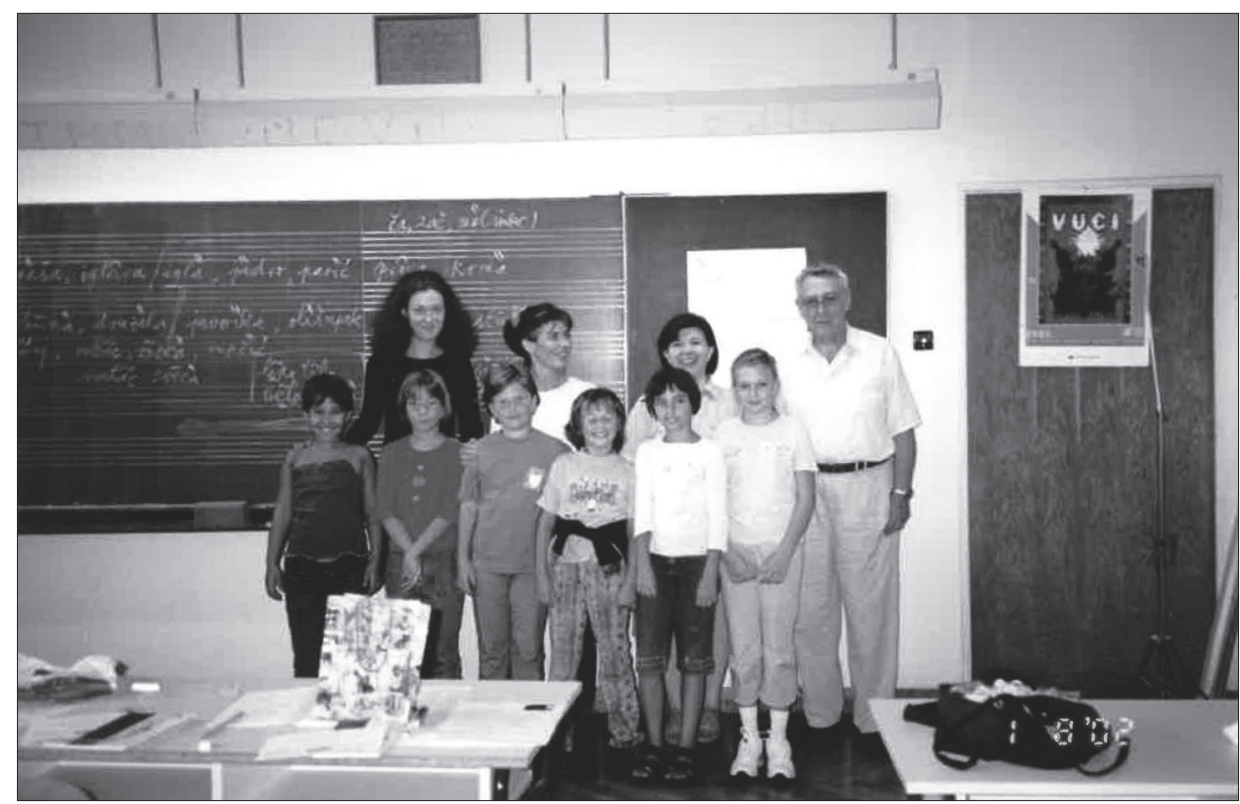

Sl. 2. Na slici u prvom redu: Dora Prpić, Katarina Tomaš, Matea Mohač, Matija Raos, Lucija Kuntić, Marija Lopac; U drugom redu: Stanka Hameršmit, Karmen Ćorić, Berta Tomljanović i akademik M. Moguš

\section{Mića letnja dijalektološka škola ${ }^{15}$}

Suradnju s akademikom Mogušem započeo sam još 1994. godine kao predsjednik Senjskog muzejskog društva, čiju sam funkciju obavljao sve do 2004. Najprije su to bili neformalni razgovori u svezi sa sadržajem Senjskog zbornika. Jedno vrijeme zajedno s prof. Antom Glavičićem i akademikom Josipom Bratulićem prof. Moguš dogovarao je prve korake u pripremi jedne cjelovite monografije Senja.

Tješnju sam suradnju postigao kada sam kao ravnatelj Osnovne škole Silvija Strahimira Kranjčevića u Senju otpočeo višegodišnje okupljanje osnovaca pod nazivom Senjski glagoljaši Ta svojevrsna trodnevna manifestacija održavala se jednom godišnje na dvije razine. Jedna razina imala je cilj okupljanje osnovaca s cijeloga područja Grada na kojoj se učila glagoljica, dok je druga kao cilj imala teorijsku razinu na kojoj su sudjelovali stručnjaci i znanstvenici iz toga područja i koji su meritorno znali na jedan prigodan način upoznavati i učenike i njihove

15 Pismohrana Osnovne škole Senj, šk. god. 2001./02. 
nastavnike s glagoljicom, kao i s brojnim djelima pisanim glagoljicom na ovim našim senjskim područjima, pa i šire. Akademik Moguš rado je boravio u našoj Osnovnoj školi. Tako je u vrijeme susreta Mladih glagoljaša u listopadu 2000. održao osnovnoškolskim nastavnicima predavanje na temu Povijest hrvatskoga jezika, a godinu dana kasnije također u listopadu, isto učiteljima i nastavnicima, predavanje pod nazivom Hrvatski pravopis u suvremenom jeziku.

Kada je dipl. ing. kemije Ante Vrhovac kao umirovljenik preuzeo dužnost predsjednika Matice hrvatske u Senju, aktivno je zagovarao i podržavao sve aktivnosti oko susreta Mladih glagoljaša u Senju. Na neki način rado je posredovao i pomagao u realizaciji susreta akademika Moguša s Osnovnom školom, ali i sa senjskom sredinom. Tako je od 23. srpnja do 1. kolovoza 2002. u Osnovnoj školi radila Mića letnja dijalektološka škola čiji je predavač bio akademik Milan Moguš. Ovu spomenutu školu pohađali su učenici iz Senja, Zagreba i Trogira, njih petnaestak. U realizaciji ove ljetne škole pomagale su učiteljice Berta Tomljanović, Karmen Ćorić i pedagoginja Karmen Boras. Na ovu svojevrsnu školsku aktivnost bili su ponosni i učenici i učitelji jer su za predavača Miće letnje dijalektološke škole u svojoj školi imali Senjanina, znamenitog znanstvenika akademika Milana Moguša.

\section{Izvori i literatura}

GLAVNI IMENIK UČENIKA PRIVATISTA (I.-VIII.) RAZREDA ZA ŠKOLSKU GODINU 1946./47. Pismohrana Srednje škole P. R. Vitezovića Senj.

GLAVNI IMENIK UČENIKA ZA ŠKOLSKU 1947./48. Pismohrana Srednje škole P. R. Vitezovića Senj.

LJETOPIS OSNOVNE ŠKOLE S. S. KRANJČEVIĆA SENJ, šk. 2001/02. Pismohrana u Osnovnoj školi.

MATICA HRVATSKA SENJ, Iz životopisa akademika Milana Moguša, Senj, 2002.

Milan MOGUŠ, Današnji senjski govor, Senjski zbornik, 2, Senj, 1966, 5-152.

Milan MOGUŠ, O Kranjčevićevim pismima V. Novaku, Senjski zbornik, 3, Senj, 1967 69, 190-195.

Milan MOGUŠ, Vitezovićeva Senjčica, Senjski zbornik, 5, Senj, 1971-73, 375-392.

Milan MOGUŠ, Jezik prijevoda Senjskoga statuta, Senjski zbornik, 13, Senj, 1988, $51-56$.

Milan MOGUŠ, Napomene o Vitezovićevu jeziku, Senjski zbornik, 13, Senj, 1988, 161 168.

Milan MOGUŠ, Uskočka epopeja u poeziji S. S. Kranjčevića, Senjski zbornik, 17, Senj, 1990, 187-192.

Milan MOGUŠ, Metropola jedne mladosti, Vijenac, 161, Zagreb, 2000. 
Milan MOGUŠ, Između Mainza i Senja, Senjski zbornik, 35, Senj, 2008, 5-10.

Milan MOGUŠ, Kako pročitati Bašćansku ploču, Senjski zbornik, 37, Senj, 2010, 33-44.

Milan MOGUŠ, Senjski zbornik Ante Glavičića, Senjski zbornik, 40, Senj, 2013, 13-18.

Milan MOGUŠ, Pričest u Smail-agi, Senjski zbornik, 41, Senj, 2014, 271-276.

PRIVATISTI (1941./42., 42./43., 45./46., 46./47., Redovni 1944./45). Pismohrana Srednje škole P. R. Vitezovića Senj.

\section{MILAN MOGUŠ, THE ACADEMIC FROM SENJ \\ $(25.04 .1927-19.11 .2017$.}

\section{Summary}

Amongst the thirty university professors and scientists from Senj the name of the academic Milan Moguš holds a prominent place. His path through life "from the thorns to the stars", or Kranjčević's "from the nest to the stars" was constantly on the up. During his working life he had significant functions in many cultural and scientific institutions throughout Croatia, as well as further afield, and this meant that he was not often able to return to his dear birthplace of Senj. He stayed here whenever he had the chance and whenever his people from Senj expressed a wish that he visit them. He was a frequent guest of the Senj Town Museum, the Senj grammar school, as well as the S. S. Kranjčević Elementary School where in his boyhood days he studied his first letters and read his first schoolbooks. This connection with Senj's cultural institutions over a number of years is less well known to the wider cultural and scientific public, therefore, it will be the theme of this article.

Keywords: Senj, grammar school, Senj Town Museum, Silvije Strahimir Kranjčević Elementary School Senj 